\title{
Prevalence and Factors Associated with Burnout Syndrome in Professionals in Basic Health Units
}

\section{PREVALENCIA Y FACTORES ASOCIADOS AL SINDROME DE BURNOUT EN PROFESIONALES DE CENTROS DE ATENCIÓN BÁSICA A LA SALUD}

Mary Sandra Carlotto', Adolfo Pizzinato ${ }^{2}$, Kátia Bones Rocha ${ }^{3}$, Rodrigo de Oliveira-Machado 4

1. Psychologist; PhD in Social Psychology (USC/ES); Professor at the Faculty of Psychology and Postgraduate Program of Psychology at Pontificia

Universidade Católica do Rio Grande do Sul (PUCRS); Productivity scholarship of CNPq. e-mail: mary.sandra@pucrs.br

2. Psychologist; PhD in Educational Psychology - Universitat Autònoma de Barcelona (UAB/ES); Professor at the Faculty of Psychology and

Postgraduate Program of Psychology (PUCRS). e-mail: Adolfo.pizzinato@pucrs.br

3. Psychologist; PhD in Psychology - Universitat Autònoma de Barcelona (UAB/ES); Professor at the Faculty of Psychology (PUCRS).

e-mail: kátia.rocha@pucrs.br

4. Psychologist; Student of Master in Social Psychology and Personality Psychology (PUCRS). e-mail: rodrigo.psicopuc@gmail.com

\section{RESUMEN}

El objetivo del estudio es identificar la prevalencia y los factores asociados a Síndrome de Burnout (SB) en 127 profesionales de salud del área metropolitana de Porto Alegre. Se trata de un estudio transversal epidemiológico. Los instrumentos utilizados fueron un cuestionario con datos sociodemográficos y laborales, la batería de evaluación de riesgos psicosociales y el Inventario de Maslach Burnout. Fueron realizados análisis de prevalencia, comparación de medias (ANOVA y test-t) y de correlación de Pearson. Los resultados muestran una prevalencia del 36,2\% de agotamiento emocional, 15,7\% de despersonalización y el 7,9\% de baja realización profesional, que cambian según la categoría profesional. El análisis de asociación muestra que cuanto menor es la edad y la experiencia profesional mayor es el agotamiento emocional. El feedback positivo de los pacientes disminuye el cansancio emocional y aumenta la realización profesional. El feedback positivo de los jefes disminuye el Agotamiento Emocional. A partir de los resultados, es posible pensar en estrategias para reducir la prevalencia de SB entre los profesionales de la salud, teniendo en cuenta las características específicas de cada grupo profesional.

(Carlotto M, Pizzinato A, Bones K, Oliveira-Machado R, 2013. Prevalencia y Factores Asociados al Síndrome de Burnout en Profesionales de Centros de Atención Básica a la Salud. Cienc Trab. MayAgo; 15 [47]: 76-80).

Palabras claves: SÍNDROME DE BURNOUT; MÉDICOS; PROFESIONALES DE LA SALUD; SALUD DEL TRABAJADOR

\section{INTRODUCTION}

The recent and profound changes in the workplace have a played key role in shaping an environment unfavorable to the health of workers. ${ }^{1}$ The current context and its different configurations have

Correspondencia / Correspondence :

Mary Sandra Carlotto

Av. Mauá, 645, apartment 504,

Centro - São Leopoldo - RS - Brazil

e-mail: mary.sandra@pucrs.br

Recibido: 20 de Marzo 2013 / Aceptado: 14 Abril de 2013

\section{ABSTRACT}

The study aims to identify the prevalence and factors associated with Burnout in 127 graduates from Basic Health Units in the municipal network of a city in the metropolitan area of Porto Alegre. The research tools used were a questionnaire to obtain socio-demographic data and employment variables, the battery of psychosocial risk assessment and the Maslach Burnout Inventory. The results showed a prevalence of 36.2\% of Emotional Exhaustion, 15.7\% of Depersonalization and of 7.9\% Professional Accomplishment. The association analysis shows that psychologists have higher levels of Emotional Exhaustion and Professional Accomplishment and doctors have higher levels of Depersonalization. The higher the pay, the higher Depersonalization and Professional Accomplishment levels go. The role conflict results in an elevation of the dimensions of Emotional Exhaustion and Depersonalization. The positive feedback from patients decreases Emotional Exhaustion and increases Professional Accomplishment, while feedback from supervisors also decreases Emotional Exhaustion.

Key words: BURNOUT SYNDROME; HEALTH PROFESSIONALS; WORKER'S HEALTH demanded a countless amount of new demands that constantly push and strain the worker into a variety of occupational stressors. Barbosa ${ }^{2}$ emphasizes the coexistence of the employment contract of indefinite duration and various forms of atypical work contracts configure the logic of flexible production, which can be exemplified by contracts for temporary work, part-time, outsourcing and internship. Developing a career in a world of instability and uncertainty is the hallmark of the condition of precarious workers and therefore more susceptible to somatic and psychosocial responses to stress, one of them being the Burnout Syndrome (BS). Burnout has received extensive attention from researchers over the last 35 years. Furthermore, burnout has been considered a public health problem. ${ }^{3}$ The prevalence of burnout 
among health care givers globally has been reported to be on the increase. ${ }^{4}$

The BS is an emotional response to situations of chronic stress due to intense relations in work situations with other people ${ }^{5,6}$, consisted by three dimensions: Emotional Exhaustion, Depersonalization and Professional Accomplishment. The Emotional Exhaustion is characterized by an absence or lack of energy and a feeling of emotional distress, having work overload as its main cause. The Depersonalization occurs when the professional starts to treat customers, colleagues and the organization in a distant and impersonal manner. Finally, the Professional Accomplishment is characterized by a tendency of the worker to self-evaluate negatively, feeling dissatisfied with his professional development, experiencing a decline in his sense of competence and his ability to interact with people. ${ }^{7}$

The syndrome has been associated with negative organizational outcomes ${ }^{8}$ and various types of personal dysfunctions, which can lead to a serious deterioration of an individual's performance at work, also affecting his family and social relationships. ${ }^{6,9}$ Currently, because of its serious consequences, the BS has been considered an important public health issue. ${ }^{10}$

Professionals dedicated to healthcare are among the ones with greatest risk of developing the $\mathrm{BS}^{11,12}$, due to the constant and persistent presence of numerous occupational stressors. Among the several, there are the long working hours, insufficient number of personal, lack of professional recognition, the high exposure of professionals to biological, chemical physical risks, as well as constant contact with suffering, pain and, many times, death. ${ }^{13,14}$ These requirements broaden when delimited to the public sector, as in addition to being forced to cope with structural difficulties (material and work, for example) to develop their work, they are frequently held accountable for them. Hence, these professionals are generally required to face with social and technical issues without being granted adequate resources ${ }^{15}$, resulting in a greater amount and intensity of occupational stressors - making them more susceptible to the development of the BS.

The literature has developed a lot of studies on Burnout in health care workers. ${ }^{15,16,17,18}$ Researches to find out more about the burnout syndrome, its consequences, and possible control in health care professionals will revert in a better physical and emotional health in health care providers and hence in the population that they care for. ${ }^{19}$

Considering the importance of the diagnosis of occupational hazards for the planning of preventive measures, this study aimes to promote the health of workers in the health area. This study intends, through a cross-sectional-observational-epidemiological design, to identify the prevalence and factors associated with BS in workers of Basic Health Units (BHU) in the municipal network of a city in the metropolitan area of Porto Alegre, Rio Grande do Sul, Brazil.

\section{METHOD}

\section{Participants}

The study included $127(88,8 \%)$ of a total of 143 health professionals, graduated technicians, distributed in 24 BHUs of a city in the metropolitan area of Porto Alegre. Among these workers, there are 30 doctors, 65 nurses, 18 dentists and 14 psychologists. Inclusion criteria were: 1 ) be professional active in a BHU for over a year and 2) not having had a sick leave in the last six months. Of the 16 professionals who did not respond to the study, five had been on sick leave and 11 did not meet the work legth criteria. Most participants were women $(82,4 \%)$, with a partner $(67,8 \%)$, with children $(60,6 \%)$ and who a have higher salary than six minimum wages, a reference in Brazil $(51,2 \%)$. The majority of the professionals works under hired employment laws $(67,5 \%)$ and work at another institution (74,2\%). Participants had an average age of 38 years $( \pm 10$ ), have an average of 12 years of professional experience $( \pm 9,5)$ and 7 years of professional experience in the health unit $( \pm 6,6)$. The workload varies from 9 to 44 hours / week, with an average of 38 hours / week $( \pm 6,7)$. The amount of patient / day treated shows a range of 10 to 200, with an average of 51 patients / day $( \pm 40)$.

\section{Instruments}

A questionnaire to obtain socio-demographic data (sex, age, marital status, children, profession) and employment data (employment length, amount of time working in the institution, workload per week in the institution, number of patients seen each day, type of contract, salary) and the following self-administered instruments: 1. Maslach Burnout Inventory ${ }^{20}$ that has a Portuguese translation validated by Lautert ${ }^{21}$. The MBI is consisted by three dimensions: Emotional Exhaustion (9 items, $\alpha=0,84$ ), Depersonalization (5 items, $\alpha=0,76$ ) and Professional Accomplishment ( 8 items, $\alpha=$ 0,73), an inverted dimension regarding the Burnout criteria. In this study, we used a Likert scale of 5 points, ranging from 0 "Never" to 4 "every day".

2. Battery of psychosocial risk assessment (Unidad de Investigación Psicosocial de la Conducta Organizacional- UNIPSICO) by Gil-Monte10, which evaluates: Autonomy ( 5 items, $\alpha=0,84$ ); role conflict ( 5 items, $\alpha=0,76$ ) Feedback (6 items, $\alpha=0,75$ ), Job Satisfaction (6 items, $\alpha$ $=0,76$ ). All items are assessed on a Likert scale of frequency of five points, ranging from 0 "Never" to 4 "every day".

\section{Procedures}

First, contact was made with the City's Health Department, to which was presented the object of the study in order to obtain the authorization and support for the implementation of the instruments. The instruments were answered in the workplace and collected after the completion of the filling. The application occurred from the period of April to September 2010 by four previously trained psychology interviewers / students. The study was approved by research ethics committees.

To calculate the prevalence, we used the cutoff points equally or higher than 3 adopted in other studies. ${ }^{22,23}$ Individuals with symptoms equally or more frequent than "often" ( 3 points in the scale) developed the Burnout symptoms characteristics. With this procedure, it is considered that subjects who stood at the midpoint of the scale (level 3) or above presented high Burnout levels. Student's t-test and ANOVA were used for the comparison of means, while the tests of Pearson's correlation was used to identify the relationship between quantitative variables, considering a significance level of 5\%.

\section{RESULTS}

The results show that the dimension of Emotional Exhaustion is the one with the highest prevalence (considering the Professional Achievement dimension inverted), as shown in Table 1.

Regarding the analysis of the relation between Burnout dimensions 
Table 1.

Prevalence of Burnout dimensions.

\begin{tabular}{|c|c|c|c|c|}
\hline Dimensions & \multicolumn{2}{|c|}{ 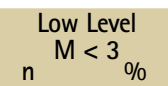 } & \multicolumn{2}{|c|}{$\begin{array}{c}\text { High Level } \\
\mathrm{M}>3\end{array}$} \\
\hline Emotional Exhaustion & 81 & 63,8 & 46 & 36,2 \\
\hline Depersonalization & 107 & 84,3 & 20 & 15,7 \\
\hline Professional Accomplishment & 10 & 7,9 & 117 & 92,1 \\
\hline
\end{tabular}

Table 2.

Link between Burnout dimensions and qualitative socio-demographic and employment variables.

\begin{tabular}{|c|c|c|c|c|c|c|c|c|c|c|}
\hline Variables & $n$ & M & $\begin{array}{l}\mathrm{EE} \\
\mathrm{DP}\end{array}$ & $\mathrm{p}$ & $\mathrm{M}$ & $\begin{array}{l}\mathrm{DE} \\
\mathrm{DP}\end{array}$ & $p$ & M & $\begin{array}{l}\text { PA } \\
\text { DP }\end{array}$ & $\mathrm{p}$ \\
\hline \multicolumn{11}{|l|}{ Sex } \\
\hline Female & 103 & 2,67 & 1,04 & 0,06 & 2,30 & 0,64 & 0,30 & 3,75 & 0,67 & 0,14 \\
\hline Male & 22 & 2,21 & 0,94 & & 2,14 & 0,49 & & 3,97 & 0,63 & \\
\hline \multicolumn{11}{|c|}{ Personal Relationships } \\
\hline With a Partner & 82 & 2,63 & 1,11 & 0,82 & 2,24 & 0,64 & 0,76 & 3,84 & 0,64 & 0,25 \\
\hline $\begin{array}{l}\text { Without a Partner } \\
\text { Children }\end{array}$ & 39 & 2,59 & 0,89 & & 2,28 & 0,51 & & 3,70 & 0,62 & \\
\hline No & 50 & 2,56 & 0,90 & 0,72 & 2,23 & 0,55 & 0,57 & 3,80 & 0,62 & 0,80 \\
\hline Yes & 77 & 2,62 & 1,12 & & 2,29 & 0,65 & & 3,77 & 0,64 & \\
\hline \multicolumn{11}{|l|}{ Type of contract } \\
\hline Statutory & 36 & 2,52 & 1,04 & 0,79 & 2,20 & 0,58 & 0,59 & 3,70 & 0,76 & 0,32 \\
\hline Contract & 79 & 2,58 & 1,07 & & 2,27 & 0,64 & & 3,83 & 0,59 & \\
\hline \multicolumn{11}{|l|}{ Formation/Major } \\
\hline Doctor & 30 & 3,01ab & 0,84 & $0,01^{*}$ & $2,56 a b$ & 0,64 & $0,01^{*}$ & $3,90 \mathrm{ac}$ & 0,53 & $0,02^{*}$ \\
\hline Nurse & 65 & 2,29bac & 0,91 & & $2,12 \mathrm{ba}$ & 0,54 & & $3,83 b$ & 0,70 & \\
\hline Psychologist & 14 & $3,17 \mathrm{cb}$ & 1,38 & & $2,37 c$ & 0,53 & & $3,30 \mathrm{ca}$ & 0,29 & \\
\hline Dentist & 18 & $2,54 d$ & 1,07 & & $2,17 d$ & 0,68 & & $3,74 d$ & 0,55 & \\
\hline
\end{tabular}

Note: * Significant difference at 5\%.

ANOVA one-way; different letters represent significantly different means through the post-hoc test by Tukey

EE: Emotional Exhaustion; DE: Depersonalization; PA: Professional Accomplishment.

Table 3.

Correlation matrix between Burnout dimensions and quantitative sociodemographic and employment variables.

$\begin{array}{lccc}\text { Variables } & \text { EE } & \text { DE } & \text { PA } \\ \text { Age } & -0,248^{* *} & -0,140 & -0,107 \\ \text { Remuneration } & 0,054 & 0,198^{*} & 0,287^{* *} \\ \text { Length of professional experience } & -0,208^{*} & -0,151 & -0,039 \\ \text { Time in the current workplace } & -0,016 & -0,094 & -0,155 \\ \text { Workload } & -0,118 & -0,174 & 0,142 \\ \text { Number of patients treated daily } & 0,150 & 0,021 & -0,114 \\ \text { Role Conflict } & 0,467^{* *} & 0,352^{* *} & -0,131 \\ \text { Autonomy } & 0,120 & 0,085 & -0,066 \\ \text { Positive feedback from patients } & -0,187^{*} & -0,130 & 0,245^{* *} \\ \text { Positive feedback from supervisors } & -0,181^{*} & -0,013 & -0,051 \\ \text { Work Satisfaction } & -0,567^{* *} & -0,267^{* *} & -0,136 \\ \text { Note: * Significant correlation level of 5\%. } & & & \\ \text { ** Significant correlation level of 1\%. } & & & \\ \text { EE: Emotional Exhaustion; DE: Depersonalization; PA: Professional Accomplishment. }\end{array}$

and socio-demographic and employment quality, it appears that only the professional education was associated with the BS dimensions. Psychologists show a higher rate of Emotional Exhaustion, differing significantly from nurses. There is also a noteworthy difference between doctors and nurses in this dimension and in Depersonalization. In regards to Professional Achievement, psychologists have the lower rates, a significant difference from doctors.

Correlation analyses of the socio-demographic and employment variables show Emotional Exhaustion will be highest with the youngest and less experienced professionals. Regarding the remuneration, it is observed that as it increases, Professional Accomplishment and Depersonalization also increases. In the psychosocial variables there is a negative association between job satisfaction and the dimensions of Emotional Exhaustion and Depersonalization. There is also a direct corelation between the levels of role conflict increasing with the levels of Emotional Exhaustion and Depersonalization. The positive feedback received from patients is associated negatively to Emotional Exhaustion and positively to Professional Accomplishment. The positive feedback from supervisors reduces the levels of Emotional Exhaustion.

\section{DISCUSSION}

The aim of this study was to identify the prevalence and factors associated with BS in BHUs. The results show that the Emotional Exhaustion dimension was the one with the greatest prevalence (considering Professional Accomplishment in its inverted form). The theoretical model of Maslach ${ }^{5}$ used in this study, characterizes BS as a process in which the Emotional Exhaustion dimension is the precursor of the syndrome, followed by Depersonalization, and, as a result, the sense of low Professional Accomplishment. The results indicate the possibility of an ongoing process, and may be momentarily being restrained by a sense of professional accomplishment at work, considering that this dimension had the greatest percentage of prevalence. ${ }^{22,24}$

The results indicate that socio-demographic, employment and psychosocial variables are associated with the Burnout dimensions. With regard to the socio-demographic and employment variables, it appears that age, remuneration, education and professional experience were associated with BS. The younger and less experienced they are, the greater the feelings of emotional distress become. Work experience has been identified as an important predictor of burnout along with age. ${ }^{25}$ This result may be related to the fact that a professional with more work experience has more confidence performing tasks, acquiring greater control of the stressors which results in a lower sense of emotional distress. Professionals beginning their careers are particularly susceptible to burnout, for they are still developing their professional knowledge base making them subsequently more dependent on their theoretical knowledge and idealism in interpreting their practice. ${ }^{26}$

In respect to remuneration, it appears that the higher the pay, the greater the sense of professional accomplishment, but also the greater the distance from the institution and the customers. One might think that, given that the sample has a majority of professionals working with an employment contract and also work at another institution, that they have a greater financial gain and therefore feel more fulfilled professionally, however, their reduced amount of time gets in the way of them developing their work closer to the institution and patients.

The results corroborate other studies that identify that there is a significant difference amongst the health professions in regards to their relation to the BS. ${ }^{27,28}$ In the present investigation it appears that psychologists had higher Emotional Exhaustion levels, differing significantly from nurses. There is also a noteworthy difference between doctors and nurses concerning this dimension as well as Depersonalization. As for Professional Accomplishment, psychologists have lower rates being significantly different from those of doctors, for example.

"Health care professionals" is a broad category of analysis, usually characterized by a general context and product. However, different 
professions may have different stressors elements that can trigger stress $^{29}$ and, in its chronicity, Burnout. One might think about this result in terms of professional formation, qualifications and expectations in the relationships with the customers. With respect to psychologists, a study by Rupert and Morgan ${ }^{30}$, which investigated Burnout in these professionals and its relation to the work environment, emphasizes that some features of the work of the psychologist, when performed in institutions, favor the development of BS. In organizational contexts, they feel less control over their activities and workload, spend more time on administrative activities, have a lower pay and take cases of higher commitment levels. These issues may explain the greater emotional exhaustion and lower sense of personal accomplishment in the psychologists that were part of the investigated sample.

The fact that doctors have shown greater Depersonalization may be related to their medical education, strongly focused on practices that are distant from the ones developed at the BHUs - usually making them less identified with their tasks. ${ }^{31}$ Although the proposed change in the curriculum of medical schools has sought to change the emphasis of medical education, it is still focused on specialization, the model of evidence-based medicine and clinical findings. ${ }^{32}$ According to a survey of medical students conducted by Ribeiro et al. ${ }^{31}$, primary health care is still seen as a form of "temporary work". The belief that in medical specialties there is a much higher income still persists and that there is a greater possibility of managing their own work. In addition, there is an idea that it is easier and less costly to keep up to date in a medical specialty than in general medicine or in community medicine.

Health practices at BHUs emphasize a much more direct and continuous contact with patients, their families and communities. This results in a greater exposure to several psychosocial, environmental and economic stressors. The lack of technical resources and lack of other professionals who derive clinical situations or social needs constitute elements that fall within the daily lives of the staffs. Vasconcelos e Zaniboni ${ }^{33}$ point out that although doctors recognize the family as the centerpiece of care in primary care, they also report that the relationship with the community ends up being a major stress factor.

In analyzing the association between psychosocial variables and Burnout dimensions, it was found that the higher the levels of job satisfaction, the lower exhaustion and emotional withdrawal levels go. This is an already consolidated relation in BS studies, revealing the importance of this feeling as a protective factor. ${ }^{34}$ This matter gains importance especially because of the influence that this variable has on the quality of work experience and on the people's desire to change their field of work. ${ }^{35}$

The role conflict implies an increase in the dimensions of Emotional Exhaustion and Depersonalization confirming the study by Tunc and Kutanis ${ }^{36}$ and Zhou and Wen. ${ }^{37}$ The conflict may occur between clients, colleagues or administrators and as a result of the several demands that go beyond what is required from the assigned role. ${ }^{38}$ One might think about what Borges et al. ${ }^{15}$, refer to in the difficulties that professionals working in the public sector face, as these professionals have to develop their work in a working context with structural difficulties and lack of resources while being charged by the customers for possible problems in the effectiveness of care. The role conflict that is established may be due to the clash between the capitalistic logic in which their work is inserted ${ }^{39}$ and the values and ideals present in the education of many health professionals. Among the reasons recognized by people working in the helping professions and care, the main one is the desire to help others, according to Edelwich and Brodsky. ${ }^{40}$ The authors have reported that Burnout would be a process of loss of idealism, energy and goals, experienced by the individual working in health care professions, related to poor conditions of their work.

The positive feedback received from patients is associated negatively to Emotional Exhaustion and positively to Professional Accomplishment. According to Tunc and Kutanis ${ }^{36}$, the health care professional spends most of his time with his colleagues and patients. In this sense, it is expected that these relationships work as protective factors from wear and a source of professional achievement. The positive perception of the social impact of work - the experience of helping others - compensates for the overhead of tasks, since the worker focuses his attention on the positive results of the customer's care. ${ }^{41}$ With respect to leadership, it is observed that the feedback reduces the feeling of emotional distress. Whereas managers have among its tasks, the function of providing feedback focused on the technical and operational part of work, this helps to reduce occupational stress factors linked to quantitative and qualitative overload that are commonly associated to the size of wear. Supervisors generally offer support in a formal nature, such as feedback related to performance, promotion opportunities, compliments, among others. ${ }^{42}$

It is crucial for preventive interventions to identify the prevalence, risk profile and early signs of Burnout development. ${ }^{43}$ In terms of diagnosis, it can be hypothesized that there is an ongoing process being contained by the high feeling of fulfillment at work. As for the risk profile, it is composed by psychologists and doctors with high pay, role conflict experience and who do not receive positive feedback from patients and supervisors.

This study has some limitations. The first is that the study has a cross-sectional design, which precludes inference in terms of causality. The second would be the healthy worker effect, a peculiar issue in cross-sectional studies in occupational epidemiology that often exclude the potentially ill. ${ }^{44}$ This is a situation that may underestimate the size of the identified risks, because the most affected are unable to remain in employment and get away through health licenses, a situation described by five professionals who make up the population. 


\section{REFERENCES}

1. Farias MD, Araújo TM de. Transtornos mentais comuns entre trabalhadores da zona urbana de Feira de Santana-BA [Common mental disorders among workers in the urban area of Feira de Santana - Bahia-Brazil]. Rev Bras Saúde Ocup. 2001;36:25-39.

2. Barbosa MAS. 0 empreendedor de si mesmo e a flexibilização no mundo do trabalho [Being one's own entrepreneur and flexibilization in the world of work]. Rev Sociol Polit. 2011;19(38):121-140.

3. Gil-Monte PR. Algunas razones para considerar los riesgos psicosociales en el trabajo y sus consecuencias en la salud pública [Some reasons to consider psychosocial occupational risks and their consequences on public health]. Rev Esp Salud Pública. 2009;83:169-173.

4. Pindar et al. Comparison of burnout syndrome among clinical and non-clinical staff of two tertiary health institutions in Maiduguri, Nigeria. Transn J Sci Technol. 2012;2: 57-73.

5. Maslach $\mathrm{C}$, Jackson SE. The measurement of experienced burnout. J Occup Behav. 1981;2:99-113.

6. Maslach C. Comprendiendo el Burnout. Cienc Trab. 2009;11:37-43.

7. Maslach C, Schaufeli WB, Leiter MP. Job burnout. Ann Rev Psychol. 2001; 52: 397-422.

8. Swider BW, Zimmerman RD. HYPERLINK "http://www.eric.ed.gov:80/ERICWeb Portal/Home.portal?_nfpb=true\&ERICExtSearch_SearchValue_0=burnout\&sea rchtype=basic\&ERICExtSearch_SearchType_0=kw\&_pageLabel=RecordDetails \&objectld=0900019b80409585\&accno=EJ878986\&_nfls=false $\% 20 \% 20 \% 20$ \%20"Born to burnout: a meta-analytic path model of personality, job burnout, and work outcomes. J Vocat Behav. 2010;76:487-506.

9. Maslach C, Leiter MP. The truth about burnout: how organization cause, personal stress and what to do about it. San Francisco: Jossey Bass; 1997.

10. Gil-Monte PR. El sindrome de quemarse por el trabajo (burnout): Una enfermidad laboral en la sociedad del bienestar [The Syndrome of Burning for a job (Burnout): An occupational disease in the society of well-being]. Madrid: Pirámide; 2005.

11. Carlotto MS. A relação profissional-cliente e a Sindrome de Burnout. Encontro. 2010;12:7-20.

12. De Dios VR, Franco VA. Prevalencia de burnout entre los profesionales de atención primaria, factores asociados y relación con la incapacidad temporal y la calidad de prescripción [Prevalence of burnout among primary health care professionals, factors associated and relations with temporary incapacity and quality of the prescription]. Semergen. 2007;33:58-64.

13. Aranda-Beltrán $C$, Pando-Moreno CM, Salazar-Estrada JG, Torres-López TM, Aldrete-Rodríguez, MG, Pérez-Reyes MB. Factores psicosociales laborales y sindrome de burnout en médicos del primer nivel de atención [Psychosocial work factors and burnout syndrome in medical primary care]. Inv Salud. 2004;5:28-34.

14. Pando MM, Bermúdez D, Aranda BC, Pérez CJ. El sindrome del Burnout en los trabajadores de la salud [Burnout syndrome in health workers]. Salud y Trabajo. 2000; 1:12-15.

15. Borges LO, Argolo JCT, Baker MCS. Os valores organizacionais e a sindrome de burnout: Dois momentos em uma maternidade pública [Organizational values and burnout syndrome: two moments in a public day-care center]. Psicol Refl Crit. 2006; 19:34-43.

16. Carlotto MS, HYPERLINK "http://lattes.cnpq.br/7902507174864967" It "_blank" Pizzinato A, Barcinski M, HYPERLINK "http://lattes.cnpq.br/3923128603940929" It "_blank"Machado R. Sindrome de Burnout em médicos e enfermeiros de Unidades Básicas de Saúde. Pessoas Sintoma. 2011;15:24-9.

17. Ebling $M$, Carlotto MS. Burnout syndrome and associated factors among health professional of public hospital. Trends Psychiatry Psychoter 2012;34:93-100.

18. Martín M J, Hernández BM, Arnillas M H, Garcia M. Burn-out en el hospital: ¿estamos quemados los médicos? [Burnout in hospital: doctors are burned?]. Med Balear. 2009;24:29-33.

19. Losa Iglesias ME, Becerro RBV, Salvadores FP. Reflections on the burnout syndrome and its impact on health care providers. Ann Afr Med 2010; 9:197-8.

20. Maslach C, Jackson SE. Maslach Burnout Inventory. Palo Alto: Consulting Psychologist Press; 1986.

21. Lautert L. O desgaste profissional: estudo empírico com enfermeiras que trabalham em hospitais. [The professional burnout: an empirical study with nurses working in hospitals]. Rev Gaúcha Enferm. 1997;18:133-144.

22. Batista JBV, Carlotto MS, Coutinho AS, Augusto LGS. Prevalência da Sindrome de Burnout e fatores sociodemográficos e laborais em professores de escolas municipais da cidade de João Pessoa, PB [Prevalence of Burnout Syndrome and sociodemographic and work factors of elementary education teachers of the City of João Pessoa]. Rev Bras Epidemiol. 2010;13:502-12.

23. Shirom A. Burnout in work organizations. In: Cooper CL, Robertson I, editors. International Review of Industrial and Organizational Psychology. New York: Wiley \& Sons; 1989. p. 25-48.

24. Carlotto M S, Palazzo LS. Sindrome de burnout e fatores associados: Um estudo epidemiológico com professores [Factors associated with burnout's syndrome: An epidemiological study of teachers]. Cad Saúde Pública. 2006;22:1017-1026.

25. Carlotto MS. Sindrome de Burnout em professores: Avaliação, fatores associados e intervenção. Porto: LivPsic; 2012.

26. Yoo J. Revisiting and rewriting early career encounters: Reconstructing one 'identity defining' moment. Aust J Teach Educ. 2011;36:105-120.

27. Grau A, Suner R, Garcia MM. Desgaste profesional en el personal sanitario y su relación con los factores personales y ambientales [Burnout syndrome in health workers and relationship with personal and environmental factors]. Gac Sanitária. 2005;19:463-70.

28. Quirós-Aragón MB, Labrador-Encinas FJ. Evaluación del estrés laboral y burnout en los servicios de urgencia extrahospitalaria [Assessment of job stress and burnout in non hospital emergency services]. Int J Clin Health Psychol. 2007;7:323-35.

29. Laranjeira CA. 0 contexto organizacional e a experiência de estress: Uma perspectiva integrativa [An integrated perspective of the organisational context and experience of stress]. Rev Salud Pública. 2009;11:123-33.

30. Rupert PA, Morgan JD. Work setting and burnout among professional psychologists. Prof Psychol-Res Pract. 2005;36:544-50.

31. Ribeiro MMF, Leal SS, Diamantino FC, Bianchi HA. A opção pela medicina e os planos em relação ao futuro profissional de estudantes de uma faculdade pública Brasileira [Students'choice of medicine and future career plans at a public medical school in Brazil]. Rev Bras Educ Med. 2011;35:405-11.

32. Moskowitz D, Bodenheimer T. Moving from Evidence-Based Medicine to Evidence-Based Health. J Gen Intern Med. 2011;26:658-60.

33. Vasconcelos F, Zaniboni M. Dificuldades do trabalho médico no PSF [Difficulties of medical working at the family health program]. Cienc Saude Coletiva. 2011;16: 1497-1504.

34. Maslach C, Schaufeli, WB. Historical and conceptual development of burnout. Professional burnout: Recent developments in theory and research New York: Taylor \& Francis; 1993. p.1-16.

35. Shapiro JP, Burkey WM, Dorman RL, Welker CJ. Job satisfaction and burnout in child abuse professionals: Measure development, factor analysis, and job characteristics. Journal of Child Sexual Abuse 1996;5:21-38.

36. Tunc $T$, Kutanis RO. Role conflict, role ambiguity, and burnout in nurses and physicians at a university hospital in Turkey. Nurs Health Sci. 2009;11:410-16.

37. Zhou Y, Wen JX. The burnout phenomenon of teachers under various conflicts. Educ Rev. 2007;4:37-44.

38. Maslach C, Goldberg J. Prevention of burnout: News perspectives. Appl Prev Psychol. 1998;7:63-74.

39. Bernardo $M H$, Seligmann-Silva $E$, Maeno $M$, Kato M. Ainda sobre a saúde mental do trabalhador [More on worker's mental heatlh]. Rev Bras Saúde Ocup. 2011;36:8-11.

40. Edelwich J, Brodsky A. Burnout: Stages of disillusionment in the helping profession. Nueva York: Human Sciences Press; 1980.

41. Grant AM, Sonnentag S. Doing good buffers against feeling bad: Prosocial impact compensates for negative task and self-evaluations. Organ Behav Hum Decision Proc 2010;111:13-22.

42. Maslach C, Jackson SE. Burnout in organizational settings. Appl Soc Psychol Ann. 1984;5:133-153.

43. Maslach C, Leiter MP. Early predictors of job burnout and engagement. J Appl Psychol. 2008;93:498-512.

44. McMichael AJ. Standardized mortality ratios and the healthy worker effect: Scratching beneath the surface. Occup Med. 1976;18:165-68. 